\title{
On the potential of water hyacinth as a biomass briquette for heating applications
}

\author{
K. Munjeri ${ }^{1} \cdot$ S. Ziuku² ${ }^{2} \cdot$ H. Maganga ${ }^{1} \cdot$ B. Siachingoma $^{3} \cdot$ S. Ndlovu $^{4}$
}

Received: 13 April 2015/Accepted: 7 October 2015/Published online: 5 November 2015

(C) The Author(s) 2015. This article is published with open access at Springerlink.com

\begin{abstract}
This article highlights the environmental challenge posed by water hyacinth on fresh water sources in Zimbabwe and investigates the use of the harvested weed as a source of energy in the form of briquettes. The water hyacinth (Eichhornia crassipes), known to be native to South America, has now become an environmental and social challenge throughout most water sources in Zimbabwe. It adversely affects the environment and humans in diverse ways. However, the plant leaves and stem release thermal energy when burned. The amount of thermal energy released depends on the moisture content and other factors. The water hyacinth organic matter and other leaf species were briquetted and their thermal energy content investigated in this exercise. The thermal energy content of the various samples was measured using a bomb calorimeter. Results of the experiments showed that the calorific value of briquetted hyacinth was $14.55 \mathrm{MJ} / \mathrm{kg}$. The calorific value of briquetted samples of other eleven leaf species ranged from 14 to $20 \mathrm{MJ} / \mathrm{kg}$. Moisture content, volatile matter and ash content results of the samples are also reported in this paper. The results show that water hyacinth briquettes can be used as thermal and lighting
\end{abstract}

\section{S. Ziuku}

sziuku@sirdc.ac.zw; sostenz@yahoo.com

1 Department of Physics, University of Zimbabwe, Box MP167, Harare, Zimbabwe

2 Energy Technology Institute, SIRDC, Box 6640, Hatcliffe, Harare, Zimbabwe

3 Physics Department, Midlands State University, P. Bag 9055, Gweru, Zimbabwe

4 Bindura University of Science Education, P. Bag 1020, Bindura, Zimbabwe energy source particularly for communities staying in the vicinity of the affected water sources.

Keywords Water hyacinth - Briquettes - Gross calorific value $\cdot$ Fixed carbon $\cdot$ Ash content

\section{Introduction}

The spread of the fast-growing water hyacinth weed in Harare's Lake Chivero and other open water sources is threatening the capital city's main water supply. Environmentalists blame the spread of the weed on the discharge of effluent, particularly raw sewage, into the Lake and its tributaries. The weed has spread, to many other water bodies throughout Zimbabwe. The plant grows rapidly and produces enormous amounts of biomass. Due to its flat top leaf structure, it covers extensive areas of open waterways.

The water weed causes ecological and economic problems by impeding navigation, fishing and recreational activities. The weed's rapid growth rate creates chronic shortage of dissolved oxygen required by the water's fauna and the flora [1,2]. Perna and Burrows [3] noted that the water hyacinth cover on water bodies reduces the gaseous exchanges that take place at the air-water interface and reduce the photosynthetic activity of submerged plants by hindering the penetration of the sun's rays. Figure 1 shows the clogged Manyame river, one of the tributaries of Lake Chivero.

In slow-moving water bodies, water hyacinth mats physically slow the flow of water, causing suspended particles to be precipitated, leading to siltation. The reduced water flow can also cause flooding and adversely affect irrigation schemes by clogging the canals and piping systems. Displacement of water by water hyacinth can mean 


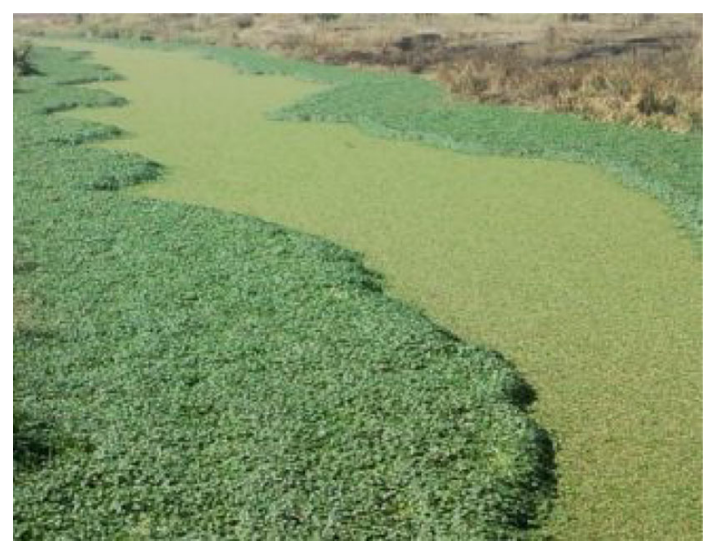

Fig. 1 Water hyacinth on Manyame River

that the effective capacity of water reservoirs is reduced by up to $400 \mathrm{~m}^{3}$ of water per hectare, causing water levels in small reservoirs to fall more rapidly in dry periods [4].

Methods for controlling the water hyacinth weed include manual and mechanical removal as well as chemical and biological interventions. Chemical use is the fastest but it has gross negative impact on the environment and water quality. The chemicals will also have to be removed to make the water safe for human consumption. Although it may be used in conjunction with other control methods, biological control is an essential option in any management plan to control the hyacinth water weed. Biological control is relatively cheap and safe for the environment giving long-term sustainable control with minimal maintenance once the weevil is established. The biological method is ideal for large areas, environmentally sensitive areas, sites where access is not possible for spraying or harvesting, sites susceptible to re-infestation and sites where water is being used for stock watering. The weevils will also disperse to other areas, including inaccessible or difficult terrain. With biological control, there is no danger of offtarget damage to, or removal of other desirable plants which can occur with herbicides or manual harvesting.

However, biological control should not be used where eradication is to be attempted unless it is to thin out a large area prior to eradication. Eradication is rarely possible with biological control, and carries the danger that the insect population will die out, and the weed will then return. The ideal situation is to achieve a dynamic equilibrium where both the plant and the insect survive at low levels without causing economic damage [5]. Large-scale mechanical processes usually require machines powered by electricity or liquid fuels. This tends to increase the process costs and damage the environment. The manual process using handheld tools is slow considering the rate at which the water weed multiplies. Nevertheless, for the purposes of productive plant utilisation, it is the best way to harvest the weed.

It has been reported that water hyacinth weed cannot be used as stock feed because of low protein content. It cannot also be used to make paper because of its short stalk length. However, it can be utilised to remove heavy metals from sewage and as an energy source in the form of briquettes. Substantial research work has been directed towards searching for various ways of realising value in the weed.

The weed is not only affecting water supply to cities and towns in Zimbabwe, but is also negatively affecting the livelihoods of people living close to the infested water bodies. These communities usually consist of the poor and vulnerable who have limited access to basic energy services. In most cases, they use wood and paraffin leading to deforestation, indoor pollution, and increased procurement costs. It is also worth noting that urban dwellers in Zimbabwe have also resorted to the traditional energy sources such as wood due to frequent electricity outages. The country's sole utility, the Zimbabwe Electricity Supply Authority (ZESA) generates about $60 \%$ of the Country's peak demand and imports power from South Africa, Mozambique and Democratic Republic of Congo in an attempt to address the shortfall [6]. Urban dwellers are also increasingly using Liquefied Petroleum Gas (LPG) for their heating needs. Imported fuels are, however, beyond the reach of many. The rural people have virtually deforested their environs in search of energy sources. The briquetting of the biomass, especially the foliage which is normally left to waste or burnt in open fires, has the potential to fill the energy gap and ensure energy sustenance in rural communities located close to the infested water bodies.

The abundance of the rapidly growing hyacinth water weed presents both environmental challenges and opportunities. It is envisaged that water hyacinth is a potential biomass material for the production of briquettes because of its high growth yield and availability in large amounts throughout the year. The present research investigates the potential use of water hyacinth from nearby watercourses as biomass material for making briquettes. The calorific value of the water weed briquettes will be compared to other briquette samples made from other leaf species.

The research motivation is how best an environmental challenge can be utilised to alleviate the energy crisis experienced by communities living in and around hyacinth water weed-infested water courses. The results of the study are expected to influence environmental and energy policy decisions on hyacinth water weed harvesting and utilisation. 


\section{Materials and methods}

\section{Leaf samples}

The water hyacinth biomass matter was manually collected from Lake Chivero which is the main water source for the City of Harare. Other leaf species used in the experiment for comparison purposes were collected from the University of Zimbabwe farm and Domboshava Training Centre, about $20 \mathrm{~km}$ north of the University. A total of 11 different leaf species were collected. Among these were 2 crops (Maize and Pumpkin) and 9 exotic (Water Hyacinth, Eucalyptus, Cypress, Calliandra calothyrsus, Acacia angustissima, Paulownia tomentosa, Flemingia macrophylla, Leucaena trichandra and Gliricidia sepium) species. The crop varieties chosen grow fast and their plant residues are abundant in rural communities. The exotic species chosen also grow fast, are abundant, and have high leaf foliage.

\section{Experimental processes}

The main procedures in the experiment are shown in Fig. 2.

The leaves were shredded into small pieces for each sample. The pieces were dried over a minimum period of 3 days and then pulverised using a pestle. A molasses binder was used to improve compactness and strength of the briquette. Various trial runs and percentage ratios were investigated to determine the amount of molasses just sufficient to bind and produce a compact briquette. A mass of $10 \%$ molasses to organic material was found to be sufficient to produce a compact briquette. The ratio was used for all leaf sample briquettes.

Briquetting was done using the hydraulic press machine in the Institute of Mining Research at the University of Zimbabwe. The mass of the samples was measured first and then mixed with the molasses binder. The mixed sample, weighing $13 \mathrm{~g}$ was then deposited into the holder of the cylindrical pressing machine. A weight used as a stopper was then placed on top of the biomass. The locking system on the machine ensured that the stopper would not come off. When activated, the hydraulic press machine compacted the biomass producing cylindrical briquettes.

\section{Calorific value determination}

The gross calorific value of briquette samples was determined in the laboratory using a bomb calorimeter. A bomb calorimeter is a sealed container which can withstand very high pressures. An ignition wire is inserted inside the bomb and this wire is used to ignite a sample of substance placed inside the bomb when a current is passed through the wire. The bomb is placed in a known quantity of water. The heat produced from the combustion is used to heat the water and routine manual monitoring of temperature and the heat calculations is taken care of by the computerised system of the bomb calorimeter. The apparatus is jacketed to prevent loss of heat. The temperature of water in the jacket is matched to temperature of water in the calorimeter vessel by a bridge circuit. The temperature rise of the system is a measure of the heat energy that is given out by the combustion sample inside the bomb. No heat transfer occurs between the water and the calorimeter as the two will be in equilibrium at all times. The process occurs adiabatically. Knowing the heat capacity of the calorimeter, the heat released from the combustion of the samples can be determined from the relationship:

$\Delta U_{b}=C_{v} \Delta T$

where $\Delta U_{\mathrm{b}}$ is the change in internal energy of the bomb calorimeter and its contents, $C_{v}$ is the heat capacity of the calorimeter, $\Delta T$ is the temperature change.

A schematic diagram of the bomb calorimeter and its contents used is shown in Fig. 3.

\section{Results and discussion}

The briquetting process produced samples with a diameter of $3.8 \mathrm{~cm}$ and a thickness of $1.1 \mathrm{~cm}$. Figure $4 \mathrm{a}, \mathrm{b}$ shows samples of the water hyacinth and maize crop briquettes.
Fig. 2 The experimental processes

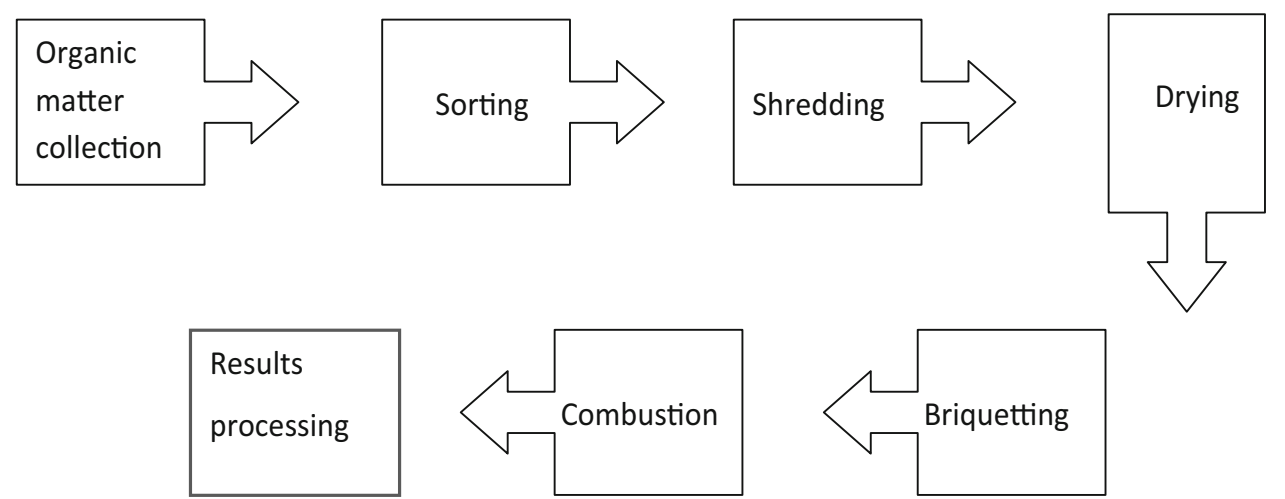




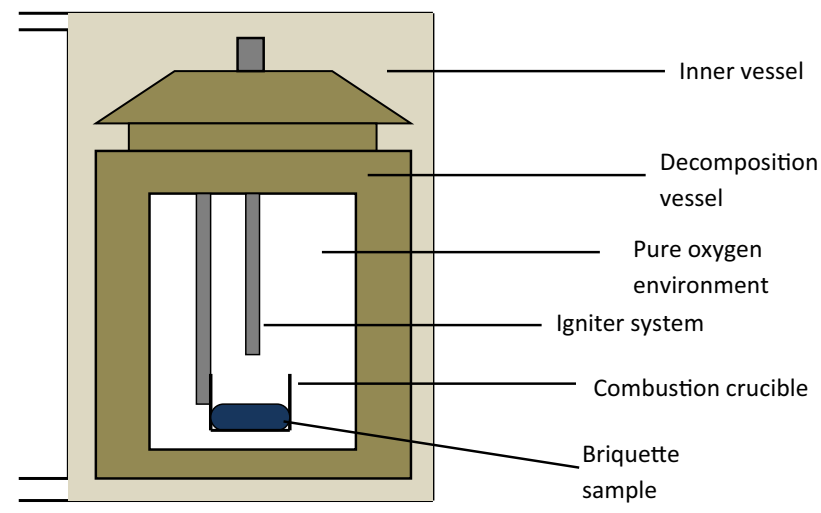

Fig. 3 Schematic illustration of a bomb calorimeter

\section{Gross calorific value measurements}

A bomb calorimeter was used to determine the gross calorific value (GCV) of the briquette samples. The measured GCV values are shown in Fig. 5.

GCV measurements showed that Acacia Angustissima leaves produced the highest gross calorific value of $20.57 \mathrm{MJ} / \mathrm{kg}$. The sample with the least calorific value was
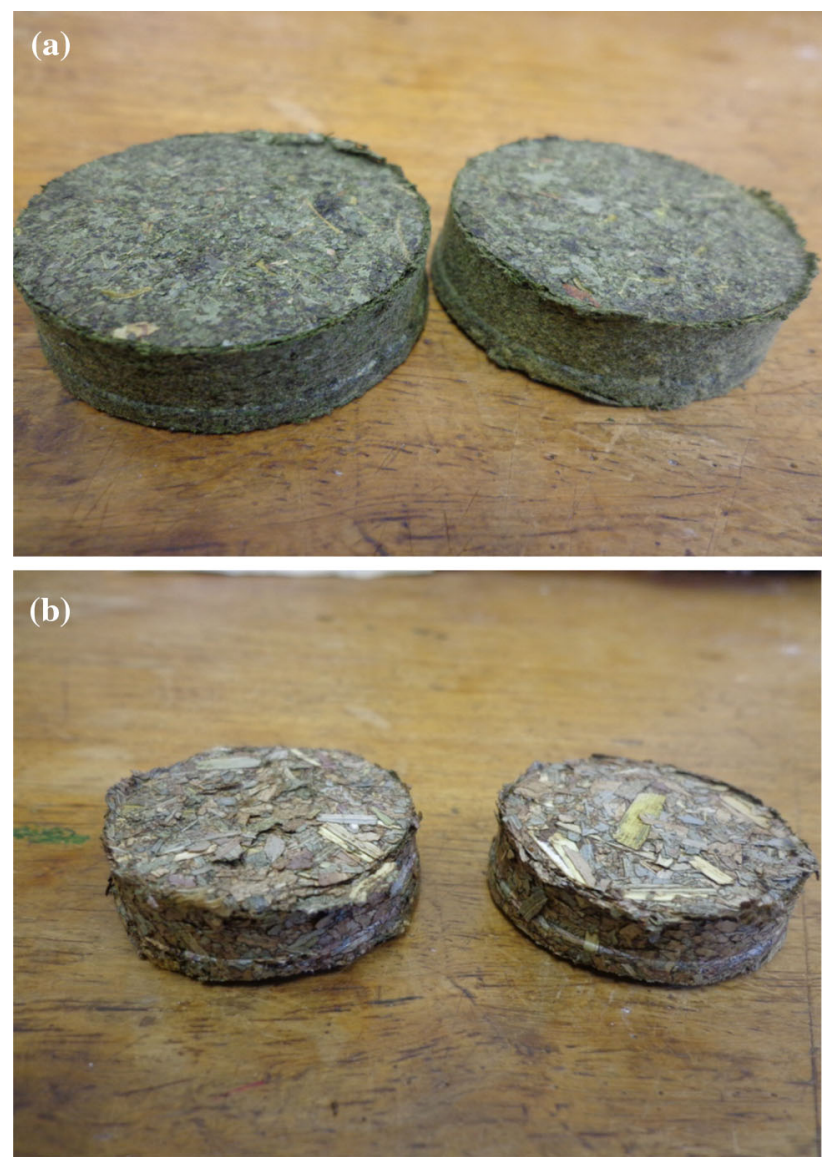

Fig. 4 a Water hyacinth briquettes. b Maize crop briquettes
Pumpkin which released $14.51 \mathrm{MJ} / \mathrm{kg}$. Water Hyacinth briquette had a heating value of $14.55 \mathrm{MJ} / \mathrm{kg}$. Of the top five species, three of them were the fast-growing exotic species sourced from Domboshava Training Centre. Data from Wankie Colliery, where most of Zimbabwe's coal is mined, indicate that local coal has GCV in the range $20-30 \mathrm{MJ} / \mathrm{kg}$. Coal is extensively used for heating purposes in industry and agriculture. The GCV of the water hyacinth briquette is about $70 \%$ of the heating energy content of the lowest commercial coal grade used in the country. Gross calorific values of selected common fuels are listed in Table 1.

Obenberger and Thek [8] reported that the GCV of woody biomass determined experimentally is around $20 \mathrm{MJ} / \mathrm{kg}$ dry mass basis, and for herbaceous biomass it is around $18.8 \mathrm{MJ} / \mathrm{kg}$ dry mass basis. As shown in Table 1, the GCV of water hyacinth briquettes compares favourably with that of wood which is predominantly used for heating and lighting in rural communities. The tabulated GCVs reveal that the water hyacinth briquette is a potential energy source for heating applications.

\section{Volatile matter}

The water and ash content, volatile matter and fixed carbon contained in the briquette samples were also determined. Table 2 depicts the fixed carbon and other physical parameters of the briquette samples.

The water hyacinth briquette has higher ash content and a lower percentage of volatile matter compared to other briquettes. The relationship between ash content, volatile matter, water content and fixed carbon with the gross calorific value is depicted in Fig. 6a, b.

An analysis of the regression coefficients for various curve fits revealed that a logarithmic model had the least squares fit described by the relation:

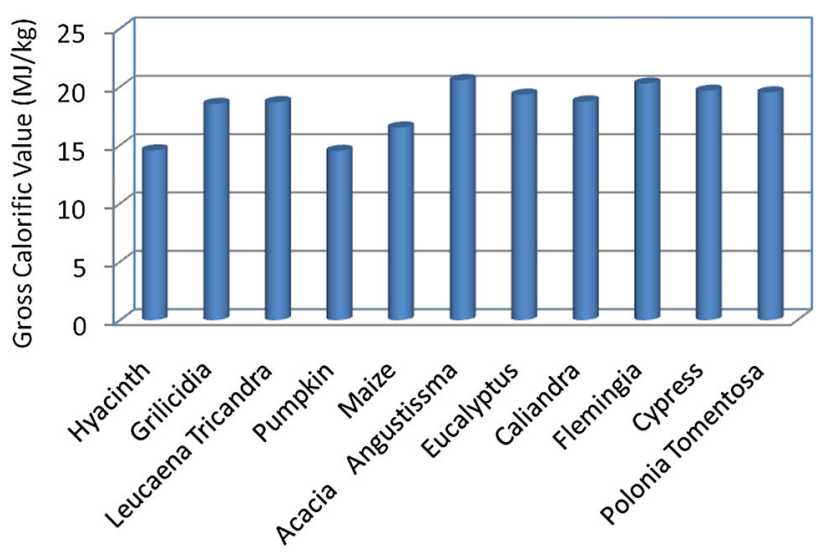

Fig. 5 Gross calorific values of the briquetted samples 
Table 1 GCV of various fuels that are usually used for heating purposes in Zimbabwe [7]

\begin{tabular}{|c|c|c|c|c|c|c|c|c|}
\hline Sample & Water hyacinth & Coal (lignite-anthracite) & Wood (dry) & Petrol & Diesel & Paraffin & Ethanol & LPG \\
\hline GCV value $(\mathrm{MJ} / \mathrm{kg})$ & 14.6 & $15.0-27.0$ & $14.4-17.4$ & 48.0 & 44.8 & 46.0 & 29.7 & 46.1 \\
\hline
\end{tabular}

Table 2 Values of water and ash content, volatile matter and fixed carbon for the various briquette samples

\begin{tabular}{lllll}
\hline Briquette sample & Water content $(\%)$ & Ash content $(\%)$ & Volatile matter $(\%)$ & Fixed carbon $(\%)$ \\
\hline Acacia Angustissima & 6.9 & 3.4 & 82.4 & 7.3 \\
Flemingia & 6.3 & 5.2 & 67.8 & 20.7 \\
Cypress & 6.3 & 6.3 & 73.2 & 20.5 \\
Paulownia tomentosa & 7.7 & 4.5 & 67.3 & 20.5 \\
Eucalyptus & 6.6 & 4.6 & 71.5 & 17.3 \\
Calliandra & 7.5 & 4.9 & 64.4 & 23.2 \\
Leucaena tricandra & 7.6 & 5.1 & 67.9 & 19.4 \\
Grilicidia & 7.2 & 4.7 & 65.4 & 22.7 \\
Maize & 7.2 & 8.4 & 66.1 & 19.5 \\
Hyacinth & 7.8 & 12.4 & 65.7 & 20.7 \\
Pumpkin & 8.3 & 11.3 & 66.2 & 14.2 \\
\hline
\end{tabular}

$y=a \ln (x)+b$

where $y$ is the gross calorific value, $x$ is the measured briquette parameter while $a$ and $b$ are the fitting constants.

Figure 6a shows that the GCV of briquettes decreases rapidly with water content and less rapidly with ash content. The GCV tends to increase with fixed carbon content. It is worth noting that the pumpkin briquette which has the highest water content (followed by water hyacinth) has the least gross calorific value. It appears that the high water content in the water hyacinth has a negative influence on the GCV of the hyacinth briquette. The heating value decreases because the thermal energy is used to evaporate the residual moisture in the briquette.

Ash is a residue of the oxidation of the mineral component of briquette samples. Lower ash content was observed in briquette samples that have higher gross calorific values. At $12.4 \%$, the water hyacinth briquette sample had higher ash content, second only to the pumpkin briquette sample. Thus, ash content suppresses the gross calorific value of briquettes. However, it is worth noting that the higher ash content in water hyacinth may be useful in replenishing trace elements removed by crops in the agricultural fields.

Volatile matter is the actual combustible matter in the fuel. It contains elements such as tar and carbon. The percentage of tar in the sample briquettes could not be determined using the calorimeter experiment. Figure $6 \mathrm{~b}$ reveals that the GCV tends to increase with volatile matter. The water hyacinth briquette's volatile matter content was found to be $65.7 \%$. The briquette sample with the highest volatile matter was observed to have the highest gross calorific value.

\section{Gaseous emissions}

The analysis of energy content of the briquettes was done concurrently with the determination of traces of gases that could be released from the combustion of the briquettes and any other elements. Elements contributing to gas emissions recorded from the experiments are sulphur, nitrogen and chlorides. Tabulated results of gaseous emissions in the briquette samples are shown in Table 3.

The eucalyptus leaf sample had the highest percentage of sulphur at $3.06 \%$. The fast-growing species all had traces of sulphur between 0.8 and $1.10 \%$. Acacia Angustissima had a sulphur trace of $0.88 \%$ which was among the lowest. Maize had the lowest percentage of sulphur at $0.66 \%$. All the species had chlorides content below $0.50 \%$.

\section{Conclusion}

In this project, fresh water hyacinth plants and other leaf samples were manually collected and briquetted in the laboratory. A molasses binder was used to improve the strength and compactness of the briquettes. A bomb calorimeter was used to measure the heat of combustion of the briquette samples. The GCV of the different briquette samples varied from 14.51 to $20.57 \mathrm{MJ} / \mathrm{kg}$. The water hyacinth briquette had a GCV of $14.55 \mathrm{MJ} / \mathrm{kg}$. This 
Fig. 6 a Variation of water, ash and fixed carbon content with GCV for various briquette samples. b Effect of volatile matter on GCV for various briquette samples
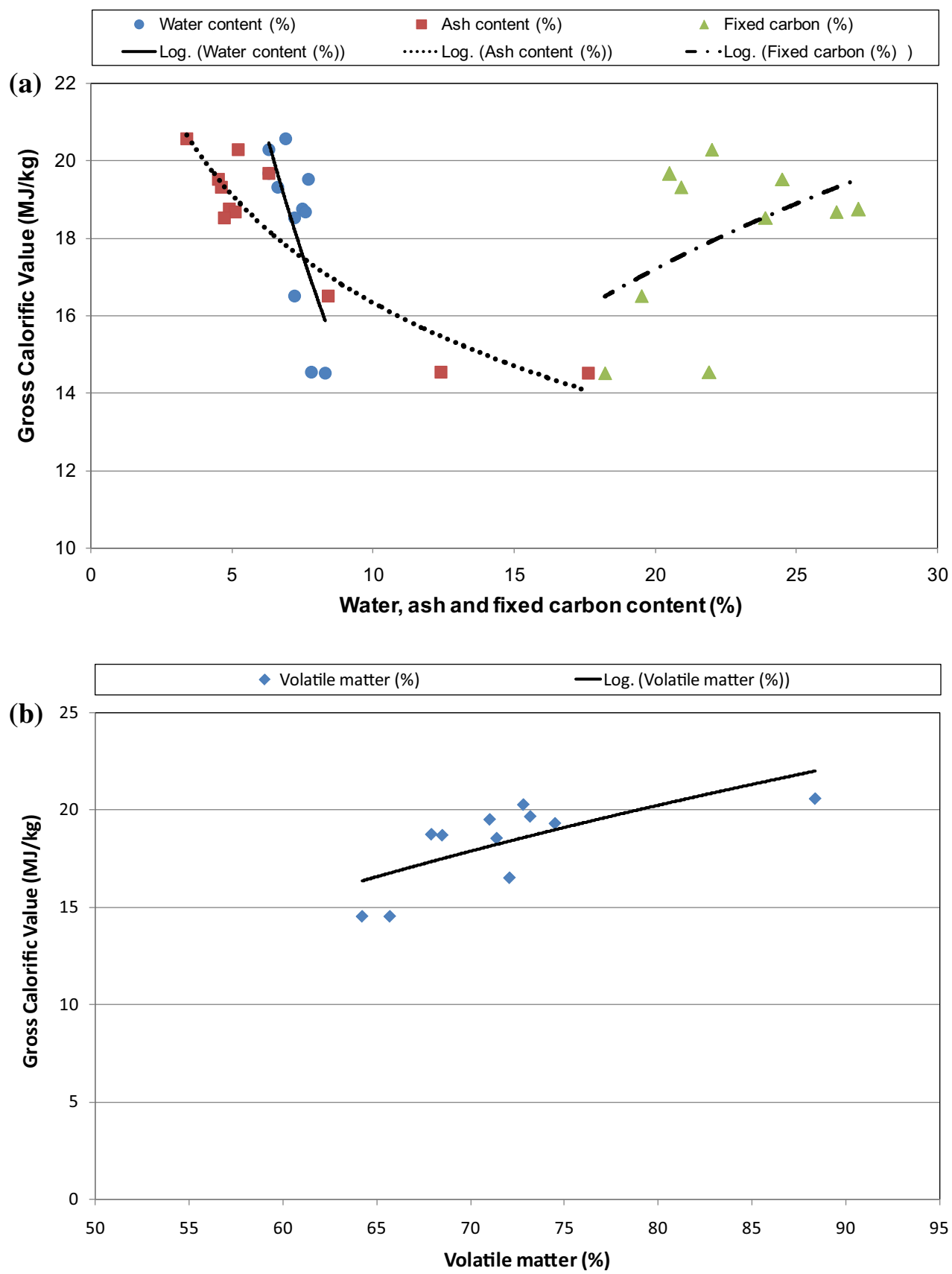

compares favourably to the GCV of wood which varies from 14.40 to $17.40 \mathrm{MJ} / \mathrm{kg}$ on dry mass basis. The GCV of briquetted water hyacinth samples was about $70 \%$ of the GCV of the lowest coal grade used for heating applications in agriculture and industry in Zimbabwe.

The water hyacinth briquette samples had average water content of $7.8 \%$, ash content of $12.4 \%$, volatile matter $65.7 \%$ and fixed carbon of $21.9 \%$. The fixed carbon content of about $20 \%$ is in the range of other woody and herbaceous plants. This exercise has shown that water hyacinth biomass can be processed into convenient solid fuel pellets using briquetting technology. The environmentally unfriendly biomass material found in various water ways can be harvested and serve as an alternative energy source.

The production of biomass briquettes from water hyacinth is recommended. This could help alleviate the challenges posed by this water weed. Successful commercialisation of the briquettes can lead to increased incomes, job creation and improved environmental management. The use of briquettes may help reduce the prevalence of the water weed in aquatic bodies and also 
Table 3 Gaseous emissions of sulphides, nitrides and chlorides

\begin{tabular}{lllll}
\hline Briquette sample & Sulphur $(\%)$ & Nitrogen $(\%)$ & Chlorides $(\%)$ & GCV (MJ/kg) \\
\hline Acacia Angustissima & 0.88 & 1.33 & 0.39 & 20.57 \\
Flemingia & 1.08 & 0.77 & 0.36 & 20.28 \\
Cypress & 0.83 & 1.88 & 0.48 & 19.66 \\
Paulownia Tomentosa & 0.82 & 1.13 & 0.46 & 19.52 \\
Eucalyptus & 3.06 & 0.86 & 0.08 & 19.32 \\
Calliandra & 1.02 & 0.69 & 0.36 & 18.74 \\
Leucaena Trichandra & 0.92 & 0.73 & 0.41 & 18.68 \\
Grilicidia & 1.00 & 0.86 & 0.36 & 18.53 \\
Maize & 0.66 & 1.02 & 0.11 & 16.51 \\
Hyacinth & 1.09 & 0.68 & 0.32 & 14.55 \\
Pumpkin & 0.94 & 0.71 & 0.43 & 14.51 \\
\hline
\end{tabular}

help reduce the intensive use of wood fuel which usually leads to deforestation.

Acknowledgments The authors wish to acknowledge the support offered by the staff of the Institute of Mining Research at the University of Zimbabwe who availed their equipment for experiments.

Author's contribution K.M. and H.M. carried out the experiments. S.Z. and K.M. supervised the work and drafted the manuscript. B.S. and S.N. both provided technical guidance, results interpretation and critically reviewed the manuscript. All authors read and approved the final article.

\section{Compliance with ethical standards}

Conflict of interest The authors declare that there are no competing interests.

Open Access This article is distributed under the terms of the Creative Commons Attribution 4.0 International License (http://crea tivecommons.org/licenses/by/4.0/), which permits unrestricted use, distribution, and reproduction in any medium, provided you give appropriate credit to the original author(s) and the source, provide a link to the Creative Commons license, and indicate if changes were made.

\section{References}

1. Seehausen, O., Witte, F., Katunzi, E.F., Smits, J., Bouton, N.: Patterns of the remnant cichlid fauna in southern Lake Victoria. Conserv. Biol. 11, 890-904 (1997)

2. Malik, A.: Environmental challenge vis a vis opportunity: the case of water hyacinth. Environ. Int. 33(1), 122-138 (2007)

3. Perna, C., Burrows, D.: Improved dissolved oxygen status following removal of exotic weed in important fish habitat lagoons of the tropical Burdekin Riva floodplain, Australia. Mar. Pollut. Bull. 51, 138-148 (2005)

4. Wittenberg, R., Cock, M.J.W. (eds.): Invasive Alien Species: A Toolkit of Best Prevention and Management Practices. CAB International, Wallingford, Oxon, UK, xvii-228 (2001)

5. Sullivan, P., Postle L.: Salvinia Biological Control Field Guide. NSW department of Primary Industries. www.dpi.nsw.gov.au/ weeds. Accessed 30 Nov 2014

6. Zimbabwe Electricity Supply Authority (ZESA). www.zesa.co.zw. Accessed 30 Jan 302015

7. Engineering Tool Box: Higher calorific values for some common fuels-coke, oil, wood, hydrogen and others. www.engineering toolbox.com. Accessed 20 Jan 302015

8. Obenberger, I., Thek, G.: The Pellet Handbook. IEA Bio-energy. Earthscan LLC, Washington, DC (2010) 